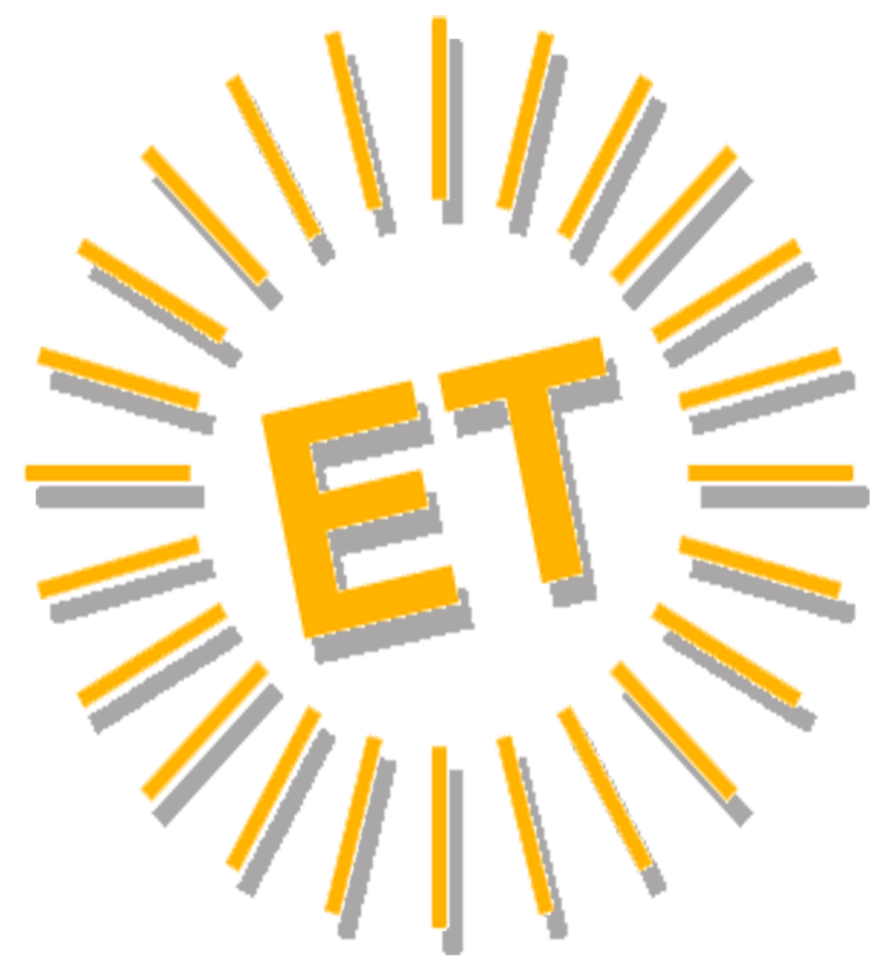




\section{Editorial Team}

\section{Editor in Chief}

Alfonso Vargas-Sánchez, University of Huelva, Spain

\section{Associate Editor}

Mirko Perano, Reald University College, Albania

\section{Books Review Editor}

Brendan Paddison, York St. John University, United Kingdom

\section{Secretariat}

Elena García de Soto, University of Huelva, Spain

Cinta Borrero-Domínguez, University of Huelva, Spain

\section{Style reviewer and text editor}

Anestis Fotiadis, I-SHOU University, Taiwan, Province of China

\section{Editorial Board}

José Manuel Alcaraz, Murdoch University, Australia Mario Castellanos-Verdugo, University of Seville, Spain José Antonio Fraiz-Brea, University of Vigo, Spain José Manuel Hernández-Mogollón, University of Extremadura, Spain

Tzung-Chen Huan, National Chiayi University, Taiwan, Province of China

Shaul Krakover, Ben Gurion University, Israel Jean Pierre Levy-Mangin, University of Quebec, Canada Tomás López-Guzmán, University of Córdoba, Spain Yasuo Ohe, Chiba University, Japón María de los Ángeles Plaza-Mejía, University of Huelva, Spain Nuria Porras-Bueno, University of Huelva, Spain João Albino Silva, Algarve University, Portugal

\section{Advisory Board (Spanish Members)}

Juan Manuel Berbel-Pineda, Pablo de Olavide University, Spain César Camisón-Zornoza, Uniersity of Valencia, Spain Enrique Claver-Cortés, University of Alicante, Spain María Teresa Fernández-Alles, University of Cádiz, Spain José Luis Galán-González, University of Seville, Spain Félix Grande-Torraleja, University of Jaén, Spain

Antonio Leal-Millán, University of Seville, Spain Inmaculada Martín-Rojo, University of Málaga, Spain Antonio Manuel Martínez-López, University of Huelva, Spain Francisco José Martínez-López, University of Huelva, Spain Pablo A. Muñoz-Gallego, University of Salamanca, Spain
Francisco Riquel-Ligero, University of Huelva, Spain José Miguel Rodríguez-Antón, Autonomous University of Madrid, Spain

Sandra Sanchez-Cañizares, University of Cordoba, Spain Josep Francesc Valls-Giménez, ESADE, Spain

\section{Advisory Board (Other European Members)}

Tindara Abbate, University of Messina, Italy Paulo Aguas, University of Algarve, Portugal Carlos Costa, Aveiro University, Portugal Dianne Dredge, Aalborg University, Denmark Salvatore Esposito de Falco, University of Rome "La Sapienza", Italy

Sheila Flanagan, Dublín Institute of Technology, Ireland Tania Gorcheva, Tsenov Academy of Economics, Bulgaria Tadeja Jere Jakulin, University of Primorska, Slovenia Metin Kozak, Mugla University, Turkey Álvaro Matias, Lusiada University, Portugal Alfonso Morvillo, National Research Council, Italy Alexandru Nedelea, Stefan cel Mare University of Suceava, Romania

Claudio Nigro, University of Foggia, Italy

Angelo Presenza, University "G. D'Annunzio" of Chieti-Pescara, Italy

Kanes Rajah, Royal Agricultural University, United Kingdom

\section{Advisory Board (Members from the rest of the world)}

John Allee, American University of Sharjah, United Arab Emirates

Nestor Pedro Braidot, National University of La Plata, Argentina

Roberto Elias Canese, Columbia University, Rector, Paraguay

Luca Casali, Queensland University of Technology, Australia Nimit Chowdhary, Indian Institute of Tourism and Travel Management, India

Steven Chung-chi Wu, National Pingtung University of Science and Technology, Taiwán

Dianne Dredge, Southern Cross University, Australia Daniel Fesenmaier, Temple University, United States

Babu George, Alaska Pacific University, United States Dogan Gursoy, Washington State University, United States Jafar Jafari, University of Wisconsin-Stout, United States Sanggun Lee, Pai Chai University, Korea Republic of Albert Yeh Shangpao, I-SHOU University, Taiwán Pauline Sheldon, University of Hawaii, United States Germán A. Sierra-Anaya, University of Cartagena de Indias, Rector, Colombia Xiaohua Yang, University of San Francisco, United States 


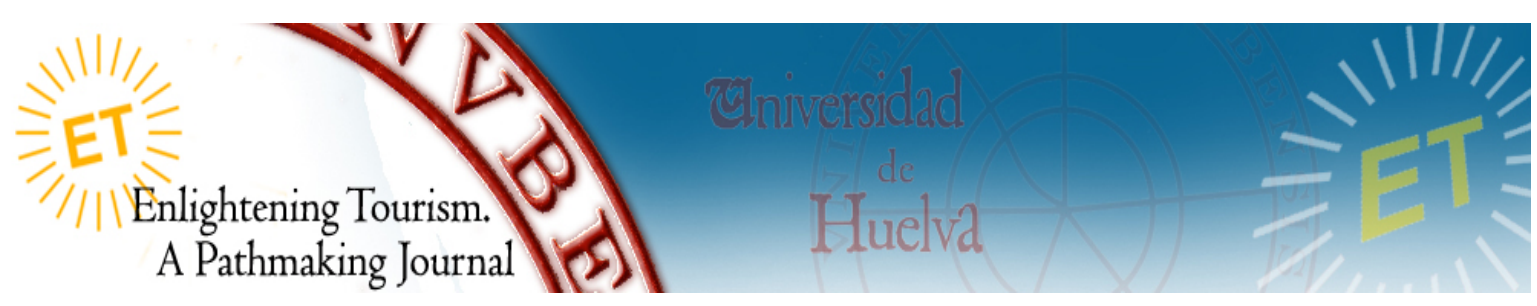

\title{
ASSESSING THE EFFECT OF AIRLINE SERVICE QUALITY ON IMAGE AND POST PURCHASE BEHAVIORAL INTENTION
}

\author{
Ramjit Singh \\ Central University of Kashmir (India) \\ ramjitmonu@yahoo.co.in \\ Abid Suhail Nika \\ Central University of Kashmir (India) \\ abids157@gmail.com
}

\begin{abstract}
The present study aimed to investigate the effect of airline service quality on image and post-purchase behavioral intention among the passengers. The exploratory cum descriptive research design was adopted. The purposive sampling technique was chosen to select valid respondents. Four hundred questionnaires were considered valid, and SPSS 25.0 was used to feed and analyze the data. The data for the study was collected through primary as well as secondary sources. The present study's essential findings are that better service quality affects airline image and post purchase behavioral intention of passengers positively. Moreover, a favorable airline image too affects the behavioral intention of passengers positively. The present research revealed that it is a better service quality and sharp airline image in a highly competitive environment that helps the airlines survive and increase their share in the market. The essential
\end{abstract}


suggestions in terms of service quality dimensions have been put forth by

the researcher to airline managers, which can surely improve passengers' memorable experiences.

KEYWORDS

Service Quality; Satisfaction; Loyalty; Image; Behavioral Intention

ECONLIT KEYS

M30; M31; M39

\section{INTRODUCTION}

Service quality plays a pivotal role in today's world towering competition, even though the tourist passengers' needs and wants differ while consuming the purchased products/services. The acquisition of positive or negative experiences is an unavoidable phenomenon. It is by dint of competitive advantage that the particular airline can enhance its competitiveness as well as reducing the ticket costs (Gerardi \&Shapiro, 2009; Stavins, 2001), simultaneously helping them in improving the relationship with travel-related agencies (Alamdari, 2002), participation in CSR activities (Ringham \& Miles, 2018; Upadhaya et al., 2018), and strengthening the horizontal type of mergers in enhancing the productivity (Yan et al., 2019). As the airline industry is service-based, $t$ experiences' are the main attributes of these products/services. The service company's product is always experiential and is treated as the overall experience (Lewis \& Chambers, 2000). Schmitt (1999) argued that the experiences which the companies offer to their passengers' are very much crucial to their success or failure. To retain the existing and attracting the new airline passengers, the companies had to create memorable experiences to increase their market share and profits (Yelkur, 2000). As per Go and Govers (2000), quality has become the most critical area of interest for private and public airline operators in the rising global market. The comparison of expected and performance is termed as service quality, i.e., SQ=P-E. A better type of service quality is established if the overall performance is more than the expected one. 
An excellent service quality helps in increasing the economic competitiveness of airlines.

Hossain (2012) revealed that the five service quality dimensions positively impact overall satisfaction, among which empathy is the strongest, followed by the rest of the dimensions. Minh and $\mathrm{Ha}$ (2015) stated that service quality is essential in attaining customer satisfaction, loyalty, and increasing business profits. It is the corporate image that acts as an imperative element in affecting loyalty among the customers (Nguyen \& LeBlanc, 2001), positive repeat patronage among the clients (Andreassen \& Lindestad, 1998), and retaining of passengers (Nguyen \& LeBlanc, 2001). Many researchers have depicted that passengers' critical determinant of satisfaction and loyalty is the corporate image (Wu, 2011).

It has been seen that service quality profoundly influences the passenger satisfaction and their loyalty. Better service quality helps develop a positive image in passengers' minds about the airlines that they travel and, in turn, positive post-purchase behavioral intention. The service providers' main task is to deliver better service quality to their clients in maximizing their satisfaction level. Earlier studies have mostly focused on studying the relationship between service quality dimensions and customer satisfaction (Archana \& Subha, 2012; Salam, Fayolle, Jaafar \& Ayupp, 2018). Meanwhile, a single research study has been carried out to examine the link among the variables of service quality, satisfaction, image, and behavioral intention (Kuo \& Tang., 2013). However, at the same time, there is a minimal application of high standard statistical techniques like SEM or PLS. Therefore, the present research is to assess Airline Service Quality on Image and Post Purchase Behavioral Intention.

\section{REVIEW OF LITERATURE AND DEVELOPMENT OF HYPOTHESES}

\section{1) SERVICE QUALITY}


According to (Oxford University Press, 2013), quality means "the standard of something as measured against other things of a similar kind or the degree of excellence of something." Quality is a dynamic force for better competitiveness, guest satisfaction, and overall profitability (Edvardsson, 1992). Service quality assesses service outcomes and processes besides comparing service expectations and performance (Parasumaran et al. 1985). Thus, service quality is a fit between the expected service level and its performance. The overall feeling of efficiency and its services of an organization termed as service quality. A service quality model has been developed by Parasuraman, Zeithaml, and Berry (1985), with worldwide acceptance.

They stated that customer satisfaction is the difference between what customer expects and what customer experiences about the service. The expectation component is established by word of mouth, self needs, and external communication while as it is by dint of "moment of truth" that the experienced component is established. The customers become satisfied only when the experienced service quality exceeds the expected level, while as when the services offered are below the expectations, the customer becomes dissatisfied. Karunaratne and Jayawardena (2010) argued that the maximum number of customers articulate their satisfaction with the overall services they experience. Hossain (2012) stated that service quality substantially impacts customers' satisfaction level, the strongest being empathy, followed by the rest of the dimensions. To assess the service quality, Hussain et al. (2015) included security and safety, and communication attributes in the aviation industry. This indicates how essential items like security, safety, and communication enhance airlines' level of services. Minh and Ha (2015) stated that service quality leads to maximum customer satisfaction and loyalty and higher profits for the business organization. There exists a positive connection between the dimensions of service quality and repurchase intention (Zeithaml et al., 1996; Cronin \& Taylor, 1992). Similarly, the impact of service quality and customer satisfaction on passengers' repeat intentions was thoroughly studied by Namukasa (2013) and Hussain (2016) in the context of the airline industry, while as the impact of 
perceived service quality on intended customer repeat intentions was studied by Gotlieb et al. (1994) and Storbacka et al. (1994). All these research findings correlated with each other and, after validation, showed significant positive relationships.

Through the mediating variable (brand image), the service quality favorably impacts the repurchase intention; both variables share multiple familiar features (Kim \& Kim, 2005; Ostrowski et al., 1993; Nyadzayo \& Khajehzadeh, 2016). Parasuraman et al. (1988) propounded a service quality model called SERVQUAL consisting of five dimensions (tangibility, assurance, empathy, reliability, and responsiveness). However, various researchers (Cronin \& Taylor, 1992; Culiberg, 2010; Hussain et al., 2015) have raised an argument about the less complete application of the SERVQUAL in measuring the various aspects of the service industry without any modifications. It is the multi-dimensional aspect of service quality that affects passenger satisfaction in airlines involving pre-flight, in-flight digital services, baggage handling mechanisms, and postflight services (Archana \& Subha, 2012). Pina et al. (2014) reported a high level of competition among the competitors; the better service quality must be maintained. This is to be done to sustain customer service quality as the critical determinant and component of its competitiveness. In airlines, the significance of service quality and demand for better service quality is a key trend among the customers (Farooq et al., 2018; Trischler \& Lohmann, 2018).

Consequently, Namukasa (2013) argued that delivering better service quality in the airline industry, the customer is of prime importance because nowadays, airline passengers are more focused on the service quality they experience. Several researchers reported the same research finding (Hussain et al., 2015; Liou et al., 2016; Jiang \& Zhang, 2016). Saei da Ardakani et al. (2015) have ranked the five dimensions of SERVQUAL, which strengthens the service quality level as presented by the airlines.

The passengers gave a good amount of importance to 'safety,' 'timeliness,' and 'variety and strengthening' in service quality factors. The service organization has a multi-layered characteristic, so it has to face severe difficulties in attaining customer 
satisfaction (Li et al., 2017). Gupta (2018) has used the 'Best Worst Method' to grade a range of service quality attributes in airlines and has concluded that the "tangibility" dimension is the most vital element of service quality. The managers of airlines should lay more thrust on the attributes of tangibility to delight passengers. In the current study, service quality has been measured using five dimensions of SERVQUAL: responsiveness, reliability, tangibility, empathy, and assurance with many more new items added to it and, at the same time, its relationship with image and tourist passengers' post-purchase intention.

\section{2) AIRLINE IMAGE}

The image is the critical asset of an organization. It is defined as "brand is reflected by the brand links held by in consumer memory". The strong association of a consumer with the organization builds up through service experience. Accordingly, they conclude by examining the past experiences with that of the company and how this consumer sets their associations. The organization has a better image that will sustain itself in a highly competitive environment and attract new and retain existing clients (Connor \& Davidson, 1997). If the company enjoys a favorable image, the customers presume that that particular company's service quality is of high quality. The customers assume that they are getting the best value of their hard-earned money (Dowling, 1994). A well-planned brand image is one of the key marketing strategies to attract maximum customers towards the company. It has been seen that the company having a good and constructive brand image shines in the market and attracts both repeat clients and trial users (Connor \& Davidson, 1997). Rhee and Haunschild (2006) established an argument that a service provider that enjoys an excellent market reputation has to suffer more adversely when committing a single mistake than the service provider with a bad market reputation. It is the brand image that acts as an imperative element in affecting loyalty (Nguyen \& LeBlanc, 2001), repeat intention (Andreassen \& Lindestad, 1998), 
and retaining of passengers (Nguyen \& LeBlanc, 2001). The brand image does not directly impact the brand attitude only but also motivates and encourages the customers to re-buy (Park et al., 2004).

The number of researchers has reported almost matching research findings, confirming and validating that brand image is essential in influencing repurchase intentions (Ataman \& Ulengin, 2003; Hsieh et al., 2004). Kotler and Keller (2012) also explored and established that brand image positively impacts repurchase intentions. There exists a strong relationship between brand image, loyalty, perceived quality, and value (Wang \& Tsai., 2014), and indeed, a brand image enhances customer loyalty. For specific brands, the clients develop both cognitive and affective responses, by which they buy these brands repeatedly (Wu et al., 2011). The airline can build trust among the customers only after developing a better repute (Hussain et al., 2015).

\section{3) BEHAVIORAL INTENTION}

There exists a positive relationship between the dimensions of service quality and repurchase intention (Cronin et al. 2000). Huang (2010) stated that customer perception of service quality is the critical success factor that positively influences customers after experiencing the services. The services which the customer has experienced in the past always come to his mind and direct whether to repurchase one more air ticket with a particular airline or not. It was established that by word of mouth, passengers share their both impressed and un-impressed attitude about the service quality they experience, which is termed as behavioral intention. The same argument was agreed by Park et al. (2004). Researchers found "that quality of services had a direct influence on customers' behavioral intentions." It was seen that customers consult their past experiences before deciding to repurchase.

The literature supports the fact that 'intention to buy the same airline service again' and 'willing to recommend it to other airline passengers' is positively affected by 
satisfaction (Bigne et al., 2001; Cronin \& Taylor, 1992). The variables like satisfaction and perceived value are the direct antecedents of behavioral intention (Tam, 2000; Petrick \& Backman, 2002). Service quality profoundly impacts passenger satisfaction in airlines. When the airline passenger is highly satisfied, it shows positive behavioral intentions for the airline tickets' future purchase. It is the service quality that contributes to an organization's success by influencing customers' loyalty and behavioral intention (Lin et al., 2009). In the travel industry, satisfied customers usually go with the service provider that satisfies them, and they recommend the same service provider to others through WOM shortly (Zabkar et al., 2010).Dolnicar et al. (2011) established that loyalty programs are strongly correlated with the customers' behavioral loyalty towards business organizations. Service quality in airlines impacts customer loyalty positively and enhances WOM publicity. Singh and Nika (2019) stated a positive impact of service quality on brand image and repeat patronage. Both the researchers supported that brand image, too, has a positive effect on repeat patronage. This indicates how significantly the companies brand image can influence the passengers' behavior to repurchase the same services (Singh \& Nika, 2019). Based on the above arguments and literature, the researchers proposed the conceptual framework (Refer to figure 1). 


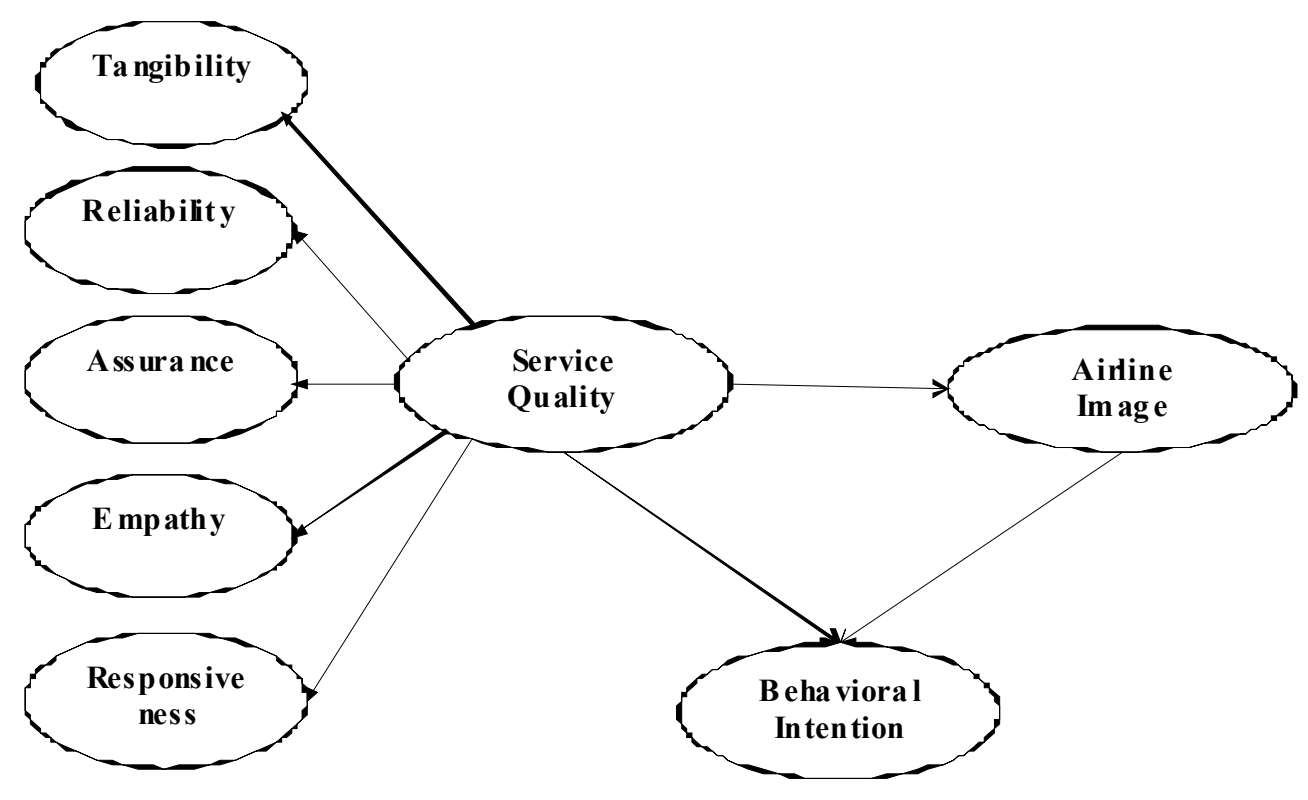

Figure 1: Conceptual Framework of the Study Source: Developed by Authors

\section{4) DEVELOPMENT OF RESEARCH HYPOTHESES}

Park et al. (2005), "the dimension of in-flight service and the dimension of convenience and accessibility were each found to positively affect airline image, which was directly related to Australian international air passengers' future behavioral intentions." Geraldine \& David U. (2013) proved a strong, statistically significant relationship between the service quality variables and the airline image. It indicates that the airline's quality of services has a positive relationship with the airline image, and the airline image also has a positive relationship with the passenger's repeat patronage. 


\section{H1: Service quality factors affect airline image positively.}

"Passenger satisfaction with the service quality dimensions (flight schedules, flight attendants, tangibles, and ground staff) is paramount in explaining behavioral intentions. The schedule mostly influences satisfied passengers. Such customers engage in positive word-of-mouth communication and have high repurchase intentions (Saha \& Theingi, 2009)". Khraim (2013) stated that "significant effect of service quality was observed about customers' behavioral intentions at the level of $(\alpha \leq 0.05)$."

\section{H2: Service quality factors affect behavioral intention positively.}

Park et al. (2004) stated that "service value, passenger satisfaction, and airline image are each found to directly affect air passengers' decision-making processes." Khraim (2013) stated that "significant effect of airline image was observed about customers' behavioral intentions at the level of $(\alpha \leq 0.05) . "$

\section{H3: Airline images affect behavioral intention positively.}

\section{RESEARCH METHODOLOGY AND DATA ANALYSIS}

\section{1) DATA COLLECTION AND SAMPLING}

The research design is exploratory cum descriptive in nature. The service attributes representing the 22- existing item scale of Parasuraman (1988) of service quality were explored /borrowed, and 16 new items were added in context to the aviation industry. While checking the reliability of the instrument, three items were deleted, and a new scale of 35 variables was used, while two items for image and four items for behavioral intention were used in the study. The total sample size was taken 
as 400 (Krejcie \& Morgan, 1970). The respondents of the study were being selected by using the purposive sampling technique. The judgment/purposive sampling technique helped make a choice-based selection of passengers whom the researcher thought would best provide the better responses necessary for the study. The purposive sampling technique was even used to give equal representation to both males and females, young and old, to make the study more rational. The present study was extended to all the domestic and foreign passengers arriving at the Srinagar International Airport (India).

Service quality dimensions (with 35 items) \& image (with two items) were assessed using 1 for 'Strongly Disagree' \& 5 for 'Strongly Agree' at the Five Point Likert Scale. Behavioral intention (with four items) was evaluated using 'extremely unlikely' and 'extremely likely' (Dagger et al. 2007; Gonzalez et al. 2007; Baker \& Crompton 2000). The reliability test was performed by calculating the "Cronbach alpha" to measure the consistency of the measurement scales. The alpha values of all the factors were above the recommended 0.70 points, which indicated that the scale was reliable (Nunnally, 1978). Cronbach's alpha values obtained were 0.88 for airline service quality, image, and tourist post-purchase behavioral intention. Data was collected from both primary as well as secondary sources. The primary data collection tool was a research questionnaire. Data was analyzed using the Exploratory Factor Analysis (EFA) and Structural Equation Modelling (SEM) approach using SPSS 25.0 and Amos 25.0. A total of 450 questionnaires were circulated among the respondents at the airports and the various hotels that had experienced the selected airlines' services. Out of the 450 questionnaires distributed, 410 were received, and a total of 400 (97.56\%) were considered valid responses and were analyzed. The maximum number of respondents were males $(59 \%)$, and simultaneously the maximum respondents were in the age group of 29 to 38 years (36\%). 30\% of respondents had their occupation as a business. Out of the total respondents, $68 \%$ were married, $30 \%$ of respondents were having their qualification as postgraduates. $30 \%$ of respondents had an income less than three lacs 
annually, and a total number of $54 \%$ of respondents had traveled with no accompanist. It has been seen that $65 \%$ of respondents have travel frequency as rarely, and $64 \%$ were repeated visitors. $62 \%$ of respondents were having their passenger class as economy, $66 \%$ of respondents have their travel purpose as leisure, and $69.25 \%$ of respondents have their nationality as domestic. The overall demographic representation is shown in the below Table 1.

\begin{tabular}{|c|c|c|c|c|c|c|c|}
\hline S. No. & $\begin{array}{l}\text { Headings } \\
(\mathrm{N}=\mathbf{4 0 0})\end{array}$ & Frequency & $\%$ & S. No. & $\begin{array}{l}\text { Headings } \\
(\mathrm{N}=\mathbf{4 0 0})\end{array}$ & Frequency & $\%$ \\
\hline 1 & \multicolumn{3}{|l|}{ Gender } & 6 & \multicolumn{3}{|l|}{ Income per year } \\
\hline & Male & 236 & 59.0 & & Less than 3 lac & 120 & 30.0 \\
\hline & Female & 162 & 40.5 & & $3-6$ lac & 104 & 26.0 \\
\hline & Transgender & 2 & 0.5 & & 6-9 lac & 72 & 18.0 \\
\hline & Total & 400 & 100 & & 9-12 lac & 56 & 14.0 \\
\hline 2 & \multicolumn{3}{|l|}{ Age (years) } & & Above 12 lac & 48 & 12.0 \\
\hline & 18 up to 28 & 142 & 35.5 & & Total & 400 & 100 \\
\hline & 29 up to 38 & 144 & 36.0 & 7 & \multicolumn{3}{|l|}{ Accompanists } \\
\hline & 39 up to 48 & 62 & 15.5 & & Yes & 184 & 46.0 \\
\hline & 49 up to 58 & 22 & 5.5 & & No & 216 & 54.0 \\
\hline & Above 58 & 30 & 7.5 & & Total & 400 & 100 \\
\hline & Total & 400 & 100 & 8 & \multicolumn{3}{|l|}{ Travel frequency } \\
\hline 3 & \multicolumn{3}{|l|}{ Occupation } & & Frequent flyer & 140 & 35 \\
\hline & Student & 80 & 20.0 & & Rarely & 260 & 65 \\
\hline & Employee & 90 & 22.5 & & Total & 400 & 100 \\
\hline & Businessman & 120 & 30.0 & 9 & \multicolumn{3}{|l|}{ Earlier Visitor } \\
\hline & Professional & 76 & 19.0 & & Yes & 256 & 64.0 \\
\hline & Any other & 34 & 8.5 & & No & 144 & 36.0 \\
\hline & Total & 400 & 100 & & Total & 400 & 100 \\
\hline 4 & \multicolumn{3}{|l|}{ Marital status } & 10 & \multicolumn{3}{|l|}{ Passenger Class } \\
\hline & Married & 272 & 68.0 & & Exec./1st class & 80 & 20.0 \\
\hline & Un-married & 120 & 30.0 & & Business Class & 72 & 18.0 \\
\hline & Divorced & 6 & 1.5 & & Economy Class & 248 & 62.0 \\
\hline & Others & 2 & 0.5 & & Total & 400 & 100 \\
\hline & Total & 400 & 100 & 11 & \multicolumn{3}{|l|}{ Purpose of Visit } \\
\hline 5 & \multicolumn{3}{|l|}{ Educational Level } & & Leisure & 264 & 66.0 \\
\hline & Under Graduate & 112 & 28.0 & & Education & 16 & 4.0 \\
\hline & Graduate & 112 & 28.0 & & Pilgrimage & 72 & 18.0 \\
\hline & Post Graduate & 152 & 38.0 & & Any other & 48 & 12.0 \\
\hline & Any other & 24 & 6.0 & & Total & 400 & 100 \\
\hline & Total & 400 & 100 & & & & \\
\hline 12 & \multicolumn{3}{|l|}{ Nationality } & & & & \\
\hline & Domestic & 277 & 69.25 & & & & \\
\hline & Foreign & 123 & 30.75 & & & & \\
\hline
\end{tabular}




\begin{tabular}{c|c|c|c|l|l|l|}
\hline & Total & 400 & 100 & & & \\
\hline \multicolumn{7}{|c|}{ Table 1: Demographic Profile of the Respondents } \\
Source: Developed by Authors
\end{tabular}

\section{2) FACTOR ANALYSIS AND DESCRIPTIVE STATISTICS}

The factor analysis technique applied to identify the underlying factors of airline service quality (independent variable), and the results presented in Table 2 . The potential influences of these assumptions' violations are minimized when the data matrix has adequate correlations, and factor analysis becomes justified. The data matrix has been examined for sufficient correlations by computing the correlation matrix, inspecting the anti-image correlation matrix, conducting Barlett's test of sphericity, and the KaiserMeyer-Olkin measure of sample adequacy has been assessed. The statistical test for the correlations among the variables is termed as Barlett's Test of Sphericity. In the current study, the value obtained for Kaiser Meyer Olkin (KMO) measure of sampling adequacy was 0.74 , which is treated as commendable and, therefore, suitable for running the factor analysis (George \& Malley, 2000).

The exploratory factor analysis was performed with the items of airline service quality to identify the various factors. The five factors identified using the SPSS software are tangibility, reliability, assertiveness, responsiveness, and empathy.

\begin{tabular}{|c|c|c|c|c|c|c|c|c|}
\hline \multirow{3}{*}{ S. No. } & \multirow{3}{*}{ Attributes } & \multicolumn{5}{|c|}{ Factor Loading } & & \\
\hline & & Factor & Factor & Factor & Factor & Factor & & \\
\hline & & 1 & 2 & 3 & 4 & 5 & & \\
\hline Fact 1 & Tangibility & & & & & & Mean & S.D \\
\hline TAN1 & $\begin{array}{l}\text { Physical appearance, dress } \\
\text { code and attitude of } \\
\text { employees of the airline you } \\
\text { traveled in }\end{array}$ & 0.92 & & & & & 4.12 & 0.94 \\
\hline TAN 2 & $\begin{array}{l}\text { Variety and excellent quality } \\
\text { of in-flight meals }\end{array}$ & 0.92 & & & & & 4.07 & 1.06 \\
\hline TAN 3 & $\begin{array}{l}\text { Modern in-flight technology } \\
\text { facilities }\end{array}$ & 0.88 & & & & & 3.89 & 1.07 \\
\hline TAN 4 & Hassle free check -in and & 0.87 & & & & & 4.11 & 0.98 \\
\hline
\end{tabular}

335 


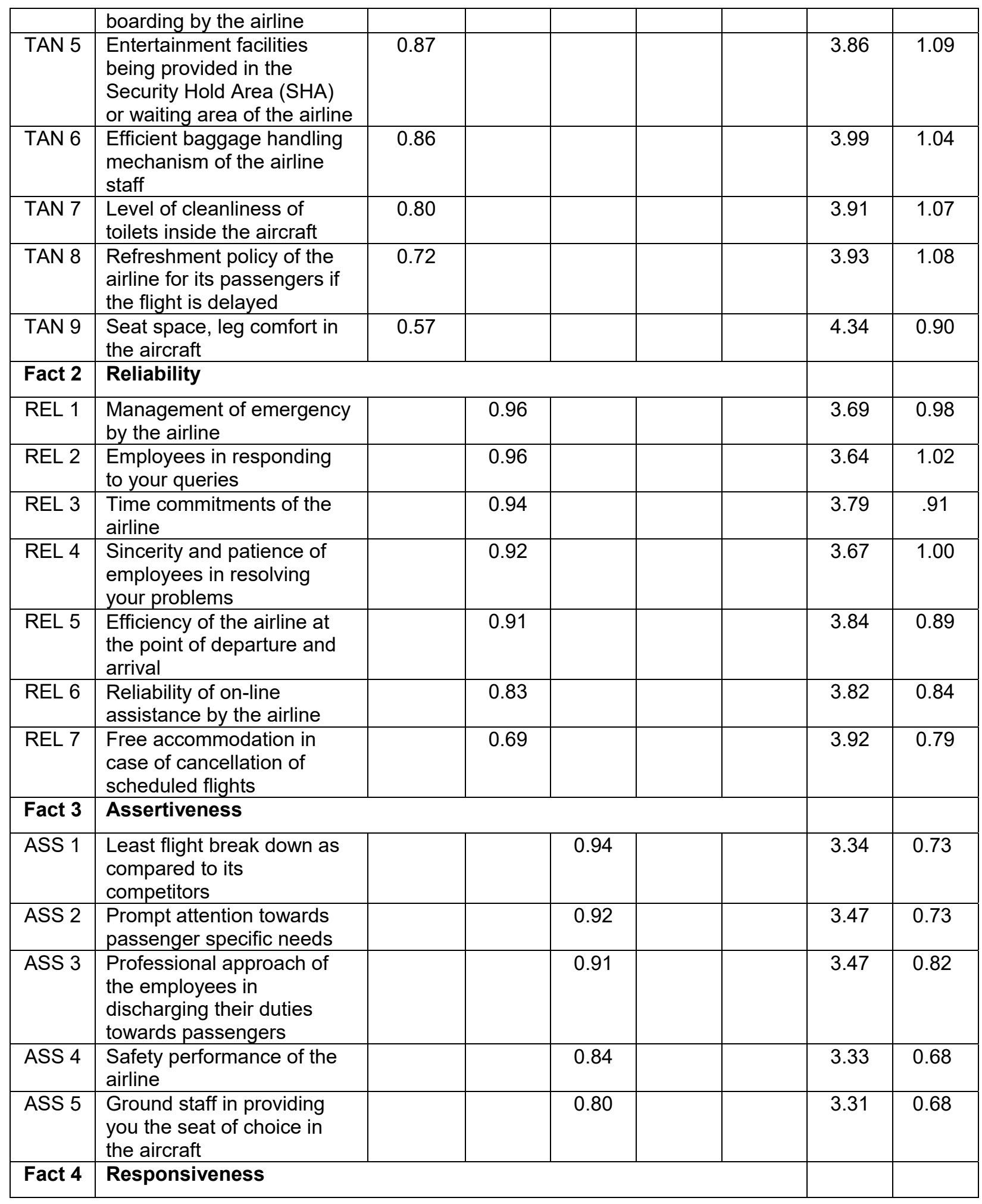




\begin{tabular}{|c|c|c|c|c|c|c|c|c|}
\hline RES 1 & Toll free number & & & & 0.95 & & 4.02 & 0.89 \\
\hline RES 2 & $\begin{array}{l}\text { On time paging call } \\
\text { (announcements) alerts }\end{array}$ & & & & 0.94 & & 4.14 & 0.85 \\
\hline RES 3 & $\begin{array}{l}\text { In-flight instructions given } \\
\text { by the crew members }\end{array}$ & & & & 0.94 & & 4.12 & 0.80 \\
\hline RES 4 & $\begin{array}{l}\text { Free SMS alerts given to } \\
\text { customers when flights } \\
\text { scheduled get canceled } \\
\text { due to bad weather or any } \\
\text { other technical faults }\end{array}$ & & & & 0.93 & & 4.13 & 0.86 \\
\hline RES 5 & Customer feedback policy & & & & 0.87 & & 3.97 & 0.97 \\
\hline Fact 5 & \multicolumn{6}{|l|}{ Empathy } & & \\
\hline EMP 1 & $\begin{array}{l}\text { Updated website all the } \\
\text { time }\end{array}$ & & & & & 0.94 & 3.76 & 0.98 \\
\hline EMP 2 & $\begin{array}{l}\text { Tourism-related } \\
\text { information }\end{array}$ & & & & & 0.92 & 3.84 & 0.98 \\
\hline EMP 3 & $\begin{array}{l}\text { Are you satisfied with the } \\
\text { care and concern taken by } \\
\text { the airline staff for its } \\
\text { passengers? }\end{array}$ & & & & & 0.91 & 3.80 & 0.98 \\
\hline EMP 4 & $\begin{array}{l}\text { Discount, cash-back given } \\
\text { by the airline on special } \\
\text { occasions }\end{array}$ & & & & & 0.89 & 3.87 & 0.96 \\
\hline EMP 5 & Grievance redress cell & & & & & 0.86 & 3.82 & 0.91 \\
\hline EMP 6 & $\begin{array}{l}\text { Tie-up of airline with travel } \\
\text { related partners, car } \\
\text { rentals, hotels etc }\end{array}$ & & & & & 0.82 & 3.61 & 1.03 \\
\hline EMP 7 & $\begin{array}{l}\text { Compensation if anyhow } \\
\text { baggage is lost or } \\
\text { damaged }\end{array}$ & & & & & 0.80 & 3.54 & 1.01 \\
\hline EMP 8 & Frequent flyer programme & & & & & 0.79 & 4.34 & 0.99 \\
\hline EMP 9 & Pricing policy & & & & & 0.77 & 3.69 & 0.99 \\
\hline & Eigen value & 6.68 & 5.20 & 2.94 & 4.74 & 8.76 & & \\
\hline & $\begin{array}{l}\text { Total Variance Explained } \\
(\%)=80.95\end{array}$ & 19.09 & 14.85 & 8.41 & 13.55 & 25.03 & & \\
\hline & Reliability Alpha (\%) & 0.94 & 0.96 & 0.93 & 0.96 & 0.95 & & \\
\hline
\end{tabular}

Table 2: Factor Analysis and Descriptive Statistics Results - Dimensions of Airline Service Quality

Source: Developed by Authors

\section{Following are the factors along with their overall mean and standard deviations:}

Tangibility: The tangibility factor of service quality is defined as being perceived by touch. It is the attribute of being easily detectable with the senses. "Parasuman, 
Ziethaml \& Berry (1988) have defined tangibility as the appearance of physical facilities, equipment, personnel, and communication materials". The total variance explained by the factor is $19.09 \%$, depicting that out of the five factors of service quality.

Reliability: It may be defined as an apparatus, machine, or system's ability to execute its required functions on demand without any failure consistently. It is concerned with a system's ability to carry out its necessary functions under fixed conditions for a particular time. "Parasuman, Ziethaml \& Berry (1988) have defined reliability as the ability to perform the promised service dependably and accurately". The total variance explained by the factor is $14.85 \%$.

Assertiveness: It is the quality of being self-assured and confident without being aggressive. "Parasuman, Ziethaml \& Berry (1988) have defined assertiveness as the knowledge and courtesy of employees and their ability to convey trust and confidence in the field of psychology; it is a learnable skill and mode of communication. The total variance explained by the factor is $8.41 \%$, depicting that out of the five service quality factors.

Responsiveness: Responsiveness means "being able to react quickly." It is the quality of people for being responsive, quickly reacting, and responding to people and events with emotion. "Parasuman, Ziethaml \& Berry (1988) have defined responsiveness as the ability to perform the promised service dependably and accurately". The total variance explained by the factor is $13.55 \%$, depicting that of the five service quality factors.

Empathy: A wide range of experiences is termed as empathy. The people can sense the emotions of others and envisage what someone might be feeling or thinking. "Parasuman, Ziethaml \& Berry (1988) have defined empathy as the provision of caring, individualized attention to customers. "The total variance explained by the factor is $25.03 \%$.

Among five factors of airline service quality, the highest overall mean achieved by the responsiveness (mean=4.10), tangibility (mean=4.02), empathy 
(mean=3.80), reliability (mean=3.76), and assertiveness (mean=3.38), which indicates that the passengers are very much satisfied with attributes of responsiveness followed by tangibility, empathy, reliability, and assertiveness. Almost all the factors have mean values above three, revealing that the passengers are getting satisfactory services at the Srinagar International Airport. However, there is a need to improve the services further. The total variance explained by the service quality variable is $80.95 \%$.

Airline Image: The variables in this factor got mean values as "you carry a good impression of this airline" (mean=3.96) and "how much you believe that airlines at the Srinagar International Airport have a better image" (mean=2.61).

Behavioral intention: It was found that the variables got their mean values as "how far you recommend the airlines operating at Srinagar International Airport to other people" (mean=2.51), "how far you would consider flying on this airline again shortly" (mean=3.57), "would you sign up for airlines' frequent flyer membership" (mean=3.75), and "would you like to travel again through the airlines whatever the cost of travel" (mean=3.86).

\section{3) CONFIRMATORY FACTOR ANALYSIS (CFA) FOR SQ MEASUREMENT MODEL}

The Structural equation modeling assumptions (SEM) were confirmed. At the same time through Confirmatory Factor Analysis (CFA), measurement model analysis was performed to validate the constructs to confirm measurement properties.

Moreover, other than Chi-square values, the researcher used recommended goodness of fit indices to check the goodness of fit of the measurement model, like CFI, IFI, GFI, AGFI, and RMSEA.

The measurement model consisting of various dimensions of service quality depicted that data is very well fit to the model $\left(X^{2}=475.9, d f=416 ; C F I=0.976\right.$; IFI $=$ 0.974; $G F I=0.856 ; A G F I=0.815$ and $R M S E A=0.035$ ). Moreover, the researcher also examined the reliability and validity of service quality dimensions by following 
Netemeyer et al. (2003). Table 3 depicts that the value of composite reliability (CR) for the model constructs have been found more than the recommended threshold value of 0.80. In all cases, values for average variance extracted (AVE) have been found more than the recommended threshold value of $\mathbf{0 . 5 0}$. The findings of the present research supported the convergent reliability and validity of measured constructs. By dint of examining the square of all pairs of correlations with average variance extracted values, the discriminant validity of the constructs was examined. In all cases, results supported that values of average variance extracted were more than the correlation square, hence supporting the discriminant validity.

\begin{tabular}{|c|c|c|c|c|}
\hline Constructs & Indicators & Loadings & AVE & CR \\
\hline 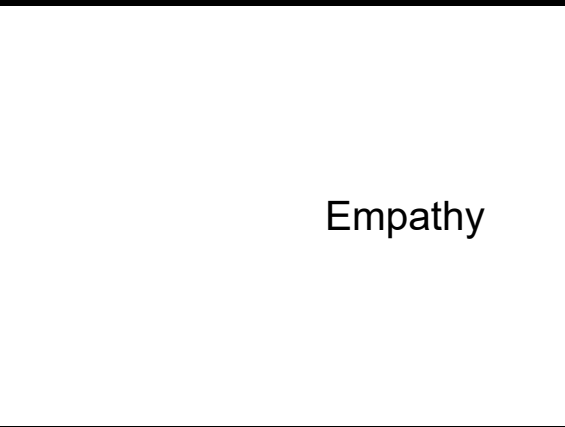 & $\begin{array}{l}\text { EMP } 7 \\
\text { EMP } 6 \\
\text { EMP } 5 \\
\text { EMP } 9 \\
\text { EMP } 8 \\
\text { EMP } 3 \\
\text { EMP } 4 \\
\text { EMP 1 } \\
\text { EMP } 2\end{array}$ & $\begin{array}{l}.82 \\
.81 \\
.77 \\
.76 \\
.72 \\
.68 \\
.76 \\
.69 \\
.73\end{array}$ & 0.747 & 0.919 \\
\hline Responsiveness & $\begin{array}{l}\text { RES } 5 \\
\text { RES } 3 \\
\text { RES } 4 \\
\text { RES } 1 \\
\text { RES } 2\end{array}$ & $\begin{array}{l}.77 \\
.81 \\
.66 \\
.71 \\
.61\end{array}$ & 0.725 & 0.846 \\
\hline Assertiveness & $\begin{array}{l}\text { ASS } 3 \\
\text { ASS } 1 \\
\text { ASS } 2 \\
\text { ASS } 5 \\
\text { ASS } 4\end{array}$ & $\begin{array}{l}.77 \\
.76 \\
.83 \\
.75 \\
.66\end{array}$ & 0.749 & 0.863 \\
\hline 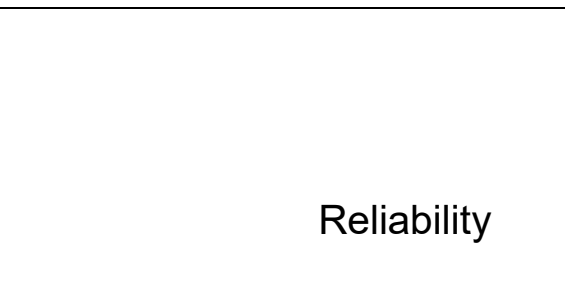 & $\begin{array}{l}\text { REL5 } \\
\text { REL } 1 \\
\text { REL } 3 \\
\text { REL } 2 \\
\text { REL } 6 \\
\text { REL } 4\end{array}$ & $\begin{array}{l}.87 \\
.67 \\
.77 \\
.69 \\
.71 \\
.65\end{array}$ & 0.786 & 0.889 \\
\hline
\end{tabular}




\begin{tabular}{|l|l|l|l|l|}
\hline & REL 7 & .77 & & \\
& & & & \\
& & & & \\
& & & & \\
& TAN 9 & .77 & & \\
& TAN 7 & .79 & & \\
& TAN 6 & .75 & & \\
& TAN 8 & .76 & \multirow{2}{*}{0.832} & 0.889 \\
& TAN 1 & .67 & 0.732 & \\
& TAN 2 & .69 & & \\
& TAN 5 & .73 & & \\
& TAN 3 & .76 & & \\
& TAN4 & .69 & & \\
\hline
\end{tabular}

Table 3: CFA loadings, AVE, and CR

Source: Developed by Authors

\section{4) GOODNESS OF FIT INDICES}

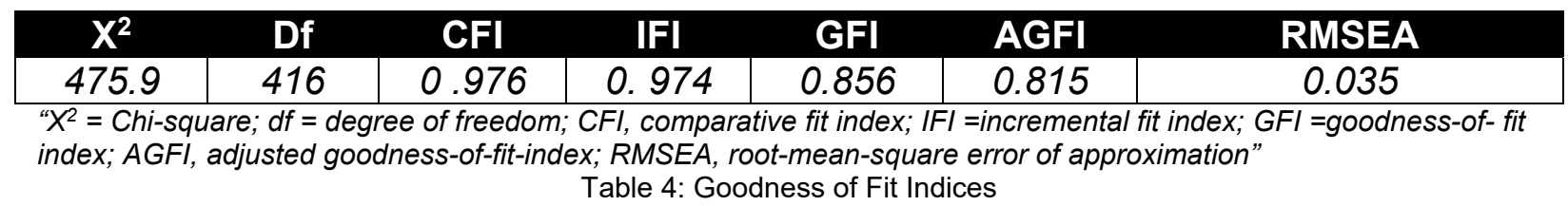

\section{5) HYPOTHESES TESTING}

When the measurement model was confirmed, the present study tested the proposed hypotheses through Structured Equation Modelling. Refer to table 5.

\begin{tabular}{|l|c|c|c|}
\hline \multicolumn{1}{c|}{ Path } & Structural Coef. & T & Test Result \\
\hline H1: Service Quality $\rightarrow$ Airline Image & .75 & 2.02 & Supported \\
\hline H2: Service Quality $\rightarrow$ Behavioral Intention & .55 & 5.96 & Supported \\
\hline H3: Airline Image $\rightarrow$ Behavioral Intention & .74 & 7.93 & Supported \\
\hline
\end{tabular}

Table 5: Hypotheses Testing

Source: Developed by Authors

\section{H1: Service Quality factors affect airline Image positively.}


The results of structural model indicated that the data is very well fitted $\left(\mathbf{X}^{\mathbf{2}}=\right.$ 436.799, df = 375; Probability level = 0.015 CFI = 0.976; IFI = 0.973; GFI = 0.843; AGFI $=0.807:$ RMR $=0.090$ and RMSEA $=0.034)$. The study revealed that service quality factors explained 67.214 on the airline image. While examining the path of coefficients, the results revealed that passengers' favorable perception towards service quality predominantly influences the airline image $(B=0.75, p<0.05)$.

\section{H2: Service quality factors affect Behavioral Intention Positively.}

The results of structural model indicated that the data is very well fitted $\left(X^{2}=\right.$ 466.729, df = 376; Probability level =0.016 CFI = 0.977; IFI = 0.972; GFI = 0.853; AGFI $=0.817:$ RMR $=0.091$ and RMSEA $=0.035)$. The study revealed that service quality factors explained $\mathbf{6 6 . 3 6 5 \%}$ of behavioral intentions. While examining the coefficients path, the results revealed that passengers' favorable perception of service quality strongly influences behavioral intentions $(B=0.55, p<0.05)$.

\section{H3: Airline image effects behavioral intention positively.}

The results of structural model indicated that the data is very well fitted $\left(X^{2}=\right.$ 456.763, df = 373; Probability level = 0.015 CFI = 0.979; IFI = 0.973; GFI = 0.855; AGFI $=0.816:$ RMR $=0.092$ and RMSEA $=0.036$ ). The study revealed that service quality factors explained $\mathbf{6 5 . 3 7 \%}$ on behavioral intentions. While examining the coefficients path, the results revealed that passengers' favorable perception of service quality influences behavioral intentions $(B=0.74, p<0.05)$.

The current study was an endeavor to assess the effect of airline service quality on image and behavioral intention from tourist passengers' perspective.

The first finding is that the constructs of service quality i.e., empathy, $(\beta=0.62)$; responsiveness, $(\beta=0.77)$; assertiveness $(\beta=0.70)$; reliability $(\beta=0.59)$; and tangibility $(\beta=0.72)$ have a significant impact on airline image (Refer to Figure 2). All these dimensions have a positive beta $(\beta)$, thereby explaining the positive impact on the airline 
image. The overall impact explained by the service quality is $\boldsymbol{\beta}=\mathbf{. 7 5}$, which indicates that it positively impacts the airline image.

The second finding is that the constructs of service quality, i.e., empathy, $(\beta$ $=0.62)$; responsiveness, $(\beta=0.77)$; assertiveness $(\beta=0.70)$; reliability $(\beta=0.59)$; and tangibility ( $\beta=0.72$ ) have a significant impact on behavioral intention (Refer to Figure 2 ). All these dimensions have a positive beta $(\beta)$, thereby explaining the behavioral intention's positive impact. The overall effect described by the service quality is $\boldsymbol{\beta}=. \mathbf{5 5}$, which indicates that it positively impacts behavioral intention.

The third finding of the study depicted that the airline image positively impacts behavioral intention (Refer to Figure 2). The airline image explains the overall impact $(\beta=.74)$ on behavioral intention, demonstrating that airline image positively impacts airline passengers. 


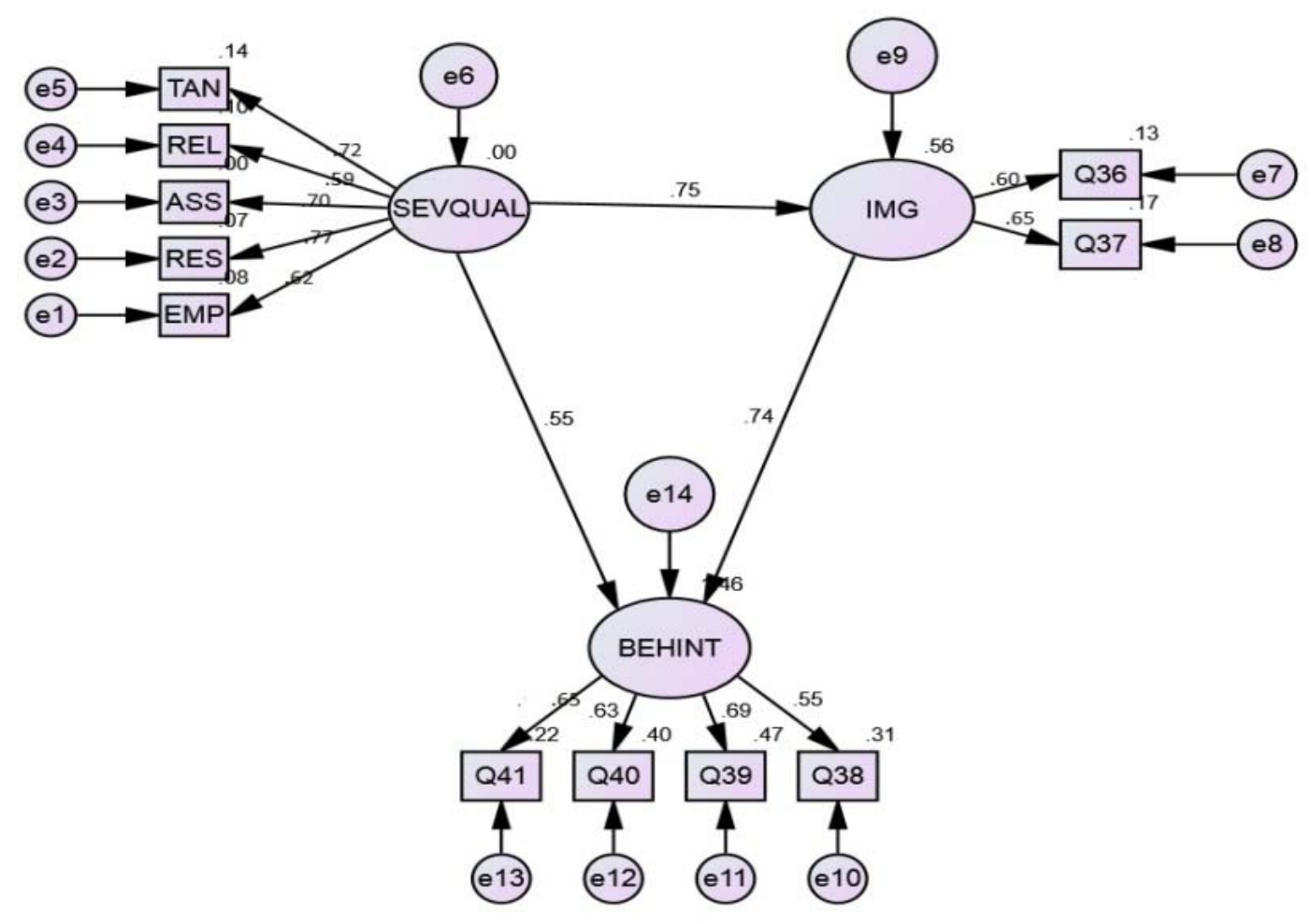

Figure 2. Structural Equation Model

Source: Developed by Authors

\section{CONCLUSION, IMPLICATIONS, AND SUGGESTIONS}

\section{1) CONCLUSION}


This paper contributes to understanding passenger satisfaction by determining service quality dimensions, which helps airline managers with practical insights on enhancing airlines' service quality. It has been concluded that excellent service quality, excellent brand image, and perceived value leads to maximum satisfaction among passengers, enhancement in brand loyalty, and positive post-purchase behavioral intention. Post-purchase behavioral intention is beneficial to the stakeholders. Tourists' better-perceived service quality significantly influences both satisfaction and loyalty (Singh \& Nika, 2019).

Further, tourist satisfaction has a more significant effect on loyalty. It has been established that better the service quality of an airline, the image created in the tourist passengers' mind directly influences its post-purchase behavioral intention. The research entails that airlines' marketing managers had to develop diverse strategies to provide excellent service quality to airline passengers because service quality affects airline image and behavioral intention positively. The failure to deliver better service quality may damage the airline's image and cause an antagonistic impact on the passengers' behavioral intentions. It has been seen that maximum airline passengers take the quality of services essential to retain their loyalty throughout the flight. To be competitive, all airlines need to improve their quality of services to maintain customer loyalty by enhancing their satisfaction level and creating a better picture in their minds. Better airline service quality increases the passengers' level of trust, further motivating them to repurchase airline tickets soon.

\section{2) MANAGERIAL IMPLICATIONS AND SUGGESTIONS}

The present research results have important implications for airline managers, particularly on the predominant influence that the satisfaction and image have on passengers' behavioral intentions. The researcher put forth the following suggestions and recommendations for the implications coming out of the current research: 
1. To enhance the modern in-flight technology facilities, the airlines should prepare themselves for Data science, Biometric-enabled self-service, Windows 8.1 Tablets for Entertainment, In-Flight Wi-Fi, In-Flight Personal Televisions, and Airsickness Bag.

2. To have a better baggage handling mechanism, they should focus on innovations like the World Tracer Tablet and Bag Message System at the Srinagar International Airport.

3. To have a sound refreshment policy, the airlines should provide lunch packs to their passengers to increase service quality, including juices, fruits, snacks, cakes, sandwiches if the flight is delayed or canceled.

4. The management should give the airlines' employees proper training on how to work together during the time of emergencies.

5. The airlines should have well improved and monitored grievances redress mechanisms for its passengers where they can register their queries and grievances so that passengers' problems are reported and addressed on a fast track basis to build up the brand image. The employees working should be trained so that they behave in a friendly manner with the passengers. They should have congenial behavior towards the passengers or customers while responding to tear queries. There should be sincerity and patience among employees in resolving the queries and problems of the passengers.

6. The airlines should try their best to follow their aircraft's time commitments (apart from the weather and natural passengers ' calamities) with full rigidity. That way, delaying in the airline operations could be minimized, and passengers can reach their destinations on time.

7. The airlines must work very hard to boost their quality of services and the approach by which services are being delivered to tourist passengers. Courtesy and patience of the ground staff employees can play a crucial role in passenger 
satisfaction to provide them with a seat of their own choice if there is the same availability.

8. The airlines shall have to shun their philosophies that they have assured market and instead act as competitors to gain competitive advantages to provide extra comfort to their passengers.

9. Better e-commerce services shall be provided to make the technology savvy and become accessible to all the people across the globe's length and breadth. It can also help in meeting tourist passenger's specific needs that, too, in no time.

10. The airlines should use safety standards as prescribed by the IATA at the Srinagar International Airport. The researcher has the (mean value=3.33) for the Safety performance variable, significantly less. IATA's Six Point Safety Strategy' is a common-driven approach to identify organizational, operational and emerging safety issues.

11. No penalty shall be imposed for rescheduling the air ticket if the passenger has a sufficient cause.

12. The airlines should provide discounts, cash-back given to their passengers on special occasions.

13. The airlines should have grievances redress cell for the passengers to register their queries and grievances, which can be sorted out under single window clearance.

\section{LIMITATIONS AND DIRECTION FOR FUTURE RESEARCH}

There were many limitations faced by the researcher in the present research. The research was conducted over four months, which allowed only summer airline tourist passengers to be surveyed. Thus, the respondents' responses would only be of a particular set of tourist passengers and not representative of year-round tourism. Ahead of time and financial constraints, the attributes selected as of the independent variable 
were not exhaustive. There could have been other attributes, which were not used in the study, demonstrating the airline image and behavioral intention. The present study did not provide full information about the behavior of the particular tourist passenger group.

Moreover, it provided direction and essential information that may help an airline enhance satisfaction, trust, and passenger loyalty. The study was confined to tourist passengers only as of the perception of general passengers' regarding service quality. The behavioral intention might be dissimilar from that of tourist passengers, so in this regard, an empirical examination needs to be done to study all types of passenger groups. Such limitations would encourage future researchers to proceed further and give additional directions so that the study's results could be further enhanced to the optimal level to enhance service quality.

\section{References}

Alamdari, F. Regional development in airlines and travel agents relationship. Journal of Air Transport Management, Vol. 8, No. 5, 2002, pp. 339-348.

Andreassen, T.W.; Lindestad, B. Customer loyalty and complex services. International Journal of Service Industry Management, Vol. 9, No. 1, 1998, pp. 7-23

Subha, M.V.; Archana, R. Passengers' perception on service quality in kingfisher airlines-An empirical research study. South Asian Journal of Marketing \& Management Research, Vol. 2, No. 12, 2012, pp. 101-107.

Ataman, B.; Ulengin, B. A note on the effect of brand image on sales. Journal of Product \& Brand Management, Vol. 12, No 4, 2003, pp. 237-250. 
Baker, D.A.; Crompton, J.L. Quality, satisfaction, and behavioral intentions. Annals of tourism research, Vol. 27, No 3, 2000, pp. 785-804.

Bigne, J.E.; Sanchez, M.I.; Sanchez, J. Tourism image, evaluation variables, and after purchase behavior: inter-relationship. Tourism Management, Vol. 22, No 6, 2001, pp. 607-616.

Connor, D.; Davidson, J. Marketing your consulting and professional services. New York: John Wiley and Sons, 1997.

Cronin, J.J.; Brady, M.; Hult, G. Assessing the effects of quality, value, and customer satisfaction on consumer behavioral intentions in service environments. Journal of Retailing, Vol. 76, No 2, 2000, pp. 193-218.

Cronin, Jr, J.J.; Taylor, S.A. (1992). Measuring service quality: a reexamination and extension. Journal of Marketing, Vol. 56, No 3, pp. 55-68.

Culiberg, B.; Rojsek, I. Identifying service quality dimensions as antecedents to customer satisfaction in retail banking. Economic and Business Review, Vol. 12, No 3 , 2010, pp. 151-166.

Dagger, T.S.; Sweeney, J.C.; Johnson, L.W. A hierarchical model of health service quality: scale development and investigation of an integrated model. Journal of Service Research, Vol. 10, No 2, 2007, pp.123-142.

Dolnicar, S.; Klaus, G.; Bettina, G.; Anna, K. Key drivers of airline loyalty. Tourism Management, Vol. 32, No. 5, 2011, pp. 1020-1026. 
Dowling, G.R.; Staelin, R. A model of perceived risk and intended risk-handling activity. Journal of Consumer Research, Vol. 21, No 1, 1994, pp.119-134.

Edvardsson, B. Service breakdowns: a study of critical incidents in an airline. International Journal of Service Industry Management, Vol. 3, No 4, 1992, pp.1729.

Eikhof, D.R.; Haunschild, A. Lifestyle meets market: Bohemian entrepreneurs in creative industries. Creativity and Innovation Management, Vol. 15, No 3, 2006, pp. 234-241.

Farooq, M.S.; Salam, M.; Fayolle, A.; Jaafar, N.; Ayupp, K. Impact of service quality on customer satisfaction in Malaysia airlines: A PLS-SEM approach. Journal of Air Transport Management, Vol. 67, No March, 2018, pp. 169-180.

George, D.; Mallery, P. SPSS for Windows Step by Step. A Simple Guide and Reference. Boston, MA: Pearson Education, 2010.

Geraldine, O.; David U., C Effects of airline service quality on airline image and passenger loyalty: Findings from Arik Air Nigeria passengers. Journal of Hospitality Management and Tourism, Vol. 4, No 2, 2013, pp. 19-28.

Gerardi, K.S.; Shapiro, A.H. Does competition reduce price dispersion? New evidence from the airline industry. Journal of Political Economy, Vol. 117, No 1, 2009, pp. 1-37.

Go, F.M.; Govers, R. Integrated quality management for tourist destinations: a European perspective on achieving competitiveness. Tourism Management, Vol. 21, No 1, 2000, pp. 79-88. 
Gonzalez, D. Ergonomia y psicosociologia. Madrid: FC Editorial, 2007.

Gotlieb, J.B.; Grewal, D. Brown, S.W. Consumer Satisfaction and Perceived Quality: Complementary or Divergent Constructs? Journal of Applied Psychology, Vol. 79, No 6, 1994, pp. 875-885.

Gupta, H. Evaluating service quality of airline industry using hybrid best worst method and VIKOR. Journal of Air Transport Management. Vol. 68, No May, 2018, pp. 35-47.

Hossain, M.J. Impact of service quality on customer satisfaction: A case of the tourism industry in Bangladesh. International Journal of Research in Finance \& Marketing, Vol.2, No 2, 2012, pp.1-25.

Hsieh, M.H.; Pan, S.L.; Setiono, R. Product, corporate, and country-image dimensions and purchase behavior: A multi-country analysis, Journal of the Academy of Marketing Science, Vol. 32, No 3, 2004, pp. 251-270.

Hussain, R. The mediating role of customer satisfaction: evidence from the airline industry, Asia Pacific Journal of Marketing and Logistics, Vol. 28, No 2, 2016, pp. 234255.

Hussain, R.; Al Nasser, A.; Hussain, Y.K. Service quality and customer satisfaction of a UAE-based airline: an empirical investigation. Journal of Air Transport Management, Vol. 42, No 1, January, 2015, pp. 167-175. 
Jiang, H.; Zhang, Y. An investigation of service quality, customer satisfaction, and loyalty in China's airline market. Journal of Air Transport Management, 57, No 1 October, 2016, pp. 80-88.

Karunaratne, W.M.K.K.; Jayawardena, L.N.A.C. Assessment of customer satisfaction in a five star hotel-A case study, Tropical Agricultural Research, Vol. 21, No 3, 2010, pp. 258-265.

Khraim, H.S. Airline Image and Service Quality Effects on Traveling Customers' Behavioral Intentions in Jordan, European Journal of Business and Management, Vol.5, No 22, 2013, pp. 20-33.

Kim, H.B.; Kim, W. G. The relationship between brand equity and firms' performance in luxury hotels and chain restaurants, Tourism Management, Vol. 26, No 4, 2005, pp. 549-560.

Kotler, P.; Keller, K.L. Marketing Management. Boston: Prentice-Hall, 2012.

Krejcie, R.V.; Morgan, D.W. Determining sample size for research activities. Educational and Psychological Measurement, Vol. 30, No 3, 1970, pp. 607610.

Kuo, C.W.; Tang, M.L. Relationships among service quality, corporate image, customer satisfaction, and behavioral intention for the elderly in high speed rail services. Journal of Advanced Transportation, Vol. 47, No 5, 2013, pp. 512-525.

Lewis, R.C.; Chambers, R.E. Marketing leadership in hospitality. New York: John Willey and Sons, Inc 2000. 
Li, W., Yu, S., Pei, H., Zhao, C., Tian, B. A hybrid approach based on fuzzy AHP and 2tuple fuzzy linguistic method for evaluation in-flight service quality. Journal of Air Transport Management, Vol. 60, No May, 2017, pp. 49-64.

Liou, J.J.; Chuang, Y.C.; Hsu, C.C. Improving airline service quality based on rough set theory and flow graphs. Journal of Industrial and Production Engineering. Vol. 33, No. 2, 2016, pp. 123-133.

Minh, N.H.; Ha, N.T.; Anh, P.C.; Matsui, Y. Service quality and customer satisfaction: A case study of the hotel industry in Vietnam. Asian Social Science, Vol. 11, No 10, 2015, pp. 73-85.

Muturi, D.; Sagwe, J.; Namukasa, J. The influence of airline service quality on passenger satisfaction and loyalty. The TQM Journal, Vol. 25, No. 5, 2013, pp. 520-532.

Namukasa, J. The influence of airline service quality on passenger satisfaction and loyalty the case of Uganda airline industry, The TQM Journal, Vol. 25, No 5, 2013, pp. 520- 532.

Netemeyer, R.G.; Bearden, W.O., Sharma, S. Scaling procedures: Issues and applications. Atlanta: Sage Publications, 2003.

Nguyen, N.; LeBlanc, G. The mediating role of corporate image on customers' retention decisions: an investigation in financial services. International Journal of Bank Marketing, Vol. 16, No. 2, 1998, pp. 52-65. 
Nguyen, N.; Leblanc, G. Corporate image and corporate reputation in customers' retention decisions in services. Journal of retailing and Consumer Services, Vol. 8, No 4, 2001, pp. 227-236.

Nunnally, J. C. Psychometric Theory. New York: McGraw-Hill, 1978.

Nyadzayo, M.W.; Khajehzadeh, S. The antecedents of customer loyalty: A moderated mediation model of customer relationship management quality and brand image, Journal of Retailing and Consumer Services, Vol. 30, No May 2016, pp. 262-270

Ostrowski, P.L.; O'Brien, T.V.; Gordon, G.L. Service Quality and Customer Loyalty in the Commercial Airline Industry, Journal of Travel Research, Vol. 32, No 2, 1993, pp.1624.

Parasuraman, A.; Zeithaml, V.A.; Berry, L.L. A Conceptual Model of Service Quality and Its Implication for Future Research, Journal of Marketing, Vol. 49, No 4, 1985, pp. 4150.

Parasuraman, A.; Zeithaml, V.A.; Berry, L.L. SERVQUAL: A multiple-item scale for measuring consumer perceptions of service quality, Journal of Retailing, Vol. 64, No Spring, 1988, pp. 12-40.

Park, J.W.; Robertson, R.; Wu, C.L. The effect of airline service quality on passengers' behavioral intentions: a Korean case study". Journal of Air Transport Management, Vol. 10, No 6, 2004, pp. 435-439. 
Petrick, J.F.; Backman, S.J. An examination of the construct of perceived value for the prediction of golf travelers' intentions to revisit. Journal of Travel Research, Vol. 41, No 1, 2002, pp. 38-45.

Pina, V.; Torres, L.; Bachiller, P. Service quality in utility industries: the European telecommunications sector. Managing Service Quality: An International Journal, Vol. 24, No 1, 2014, pp. 2-22.

Rhee, M.; Haunschild, P.R. The liability of good reputation: A study of product recalls in the US automobile industry. Organization Science, Vol. 17, No 1, 2006, pp. 101-117.

Ringham, K.; Miles, S. The boundary of corporate social responsibility reporting: the case of the airline industry. Journal of Sustainable Tourism, Vol. 26, No 7, 2018, pp. 120.

Saeida Ardakani, S.; Nejatian, M.; Farhangnejad, M.A.; Nejati, M. A fuzzy approach to service quality diagnosis. Marketing Intelligence \& Planning, Vol. 33, No 1, 2015, pp. 103-119.

Saha, G.C.; Theing. Service quality, satisfaction, and behavioural intentions. Managing Service Quality: An International Journal, Vol. 19, No 3, 2009, pp. 350-372.

Schmitt, B.H. Experiential marketing: How to get customers to sense, feel, think, act, and relate to your company and brands. New York: Free Press, 1999.

Shieh, J.I.; Wu, H.H.; Huang, K.K. A DEMATEL method in identifying key success factors of hospital service quality. Knowledge-Based Systems, Vol. 23, No 3, 2010, pp. 277-282. 
Singh, R.; Nika, A.S. Influence of Service Quality on Brand Image and Repeat Patronage in the Hospitality Industry: A Content Analysis. African Journal of Hospitality, Tourism, and Leisure, Vol. 8, No 3, 2019, pp. 1-19.

Stavins, J. Price discrimination in the airline market: the effect of market concentration. Review of Economics and Statistics, Vol. 83, No 1, 2001, pp. 200-202.

Storbacka, K.; Strandvik, T.; Gronroos, C. Managing Customer Relationships for Profit: The Dynamics of Relationship Quality, International Journal of Service Industry Management, Vol. 5 No. 5, 1994, pp. 21-38.

Tam, J.L.M. The effects of service quality, perceived value, and customer satisfaction on behavioral intentions. Journal of Hospitality and Leisure Marketing, Vol. 6, No 4, 2000, pp. 31-43.

Trischler, J.; Lohmann, G. Monitoring quality of service at Australian airports: A critical analysis. Journal of Air Transport Management, Vol. 67, No March, 2018. pp. 63-71.

Upadhaya, B.; Munir, R.; Blount, Y.; Su, S. Diffusion of corporate social responsibility in the airline industry. International Journal of Operations \& Production Management, Vol. 38, No 4, 2018. pp. 1020-1040.

Wang, S.; Qu, X.; Yang, Y. Estimation of the perceived value of transit time for containerized cargoes. Transportation Research Part A: Policy and Practice, Vol. 78, No August, 2015, pp. 298-308. 
Wang, Y.H.; Tsai, C.F. The relationship between brand image and purchase intention: Evidence from award-winning mutual funds. The International Journal of Business and Finance Research, Vol. 8, No 2, 2014, pp. 27-40.

Wu, P.C.S.; Yeh, G.Y.Y.; Hsiao, C.R. The effect of store image and service quality on brand image and purchase intention for private label brands. Australasian Marketing Journal, Vol. 19, No 1, 2011, pp. 30-39.

Yan, J.; Fu, X.; Oum, T.H.; Wang, K. Airline horizontal mergers and productivity: empirical evidence from a quasi-natural experiment in China. International Journal of Industrial Organization, Vol. 62, No January, 2019, pp. 358-376.

Yelkur, R. Customer satisfaction, and the services marketing mix. Journal of Professional Services Marketing, Vol. 21, No 1, 2000, pp.105-115.

Zabkar, V.; Brencic, M.M.; Dmitrovic, T. Modeling perceived Quality, visitor satisfaction, and behavioral intentions at the destination level. Tourism Management, Vol. 31, No 4, 2010, pp. 537-546.

Zeithaml, V.A.; Berry, L.L.; Parasuraman, A. The Behavioral Consequences of Service Quality, Journal of Marketing, Vol. 60, No 2, 1996, pp. 31-46.

Article info: Received 20/03/2020. Accepted 09/10/2020. Refereed anonymously. 